Paedagogia Christiana

I/29 (2012) - ISSN 1505-6872

Piotr Chrzczonowicz*

Toruń

\title{
Idea końca świata w doktrynach i praktykach tzw. sekt i nowych ruchów religijnych, Toruń, 7 grudnia 2011 roku
}

W dniu 7 grudnia 2011 r. na Wydziale Teologicznym Uniwersytetu Mikołaja Kopernika w Toruniu odbyło się III Toruńskie Sympozjum poświęcone Sektom i Nowym Ruchom Religijnym zatytułowane Idea końca świata $w$ doktrynach i praktykach tzw. sekt i nowych ruchów religijnych. Sympozjum zorganizowane zostało przez Wydział Teologiczny UMK, Katedrę Prawa Karnego i Polityki Kryminalnej Wydziału Prawa i Administracji UMK, Pracownię Dokumentacji i Badań Alternatywnych Ruchów Religijnych i Parareligijnych UMK, Centrum Badań nad Mniejszościami Religijnymi w Toruniu, Toruńskie Centrum Informacji o Sektach i Ruchach Religijnych oraz Samorząd Studencki Wydziału Teologicznego UMK. Ponadto w organizacji sympozjum partycypowały i inne podmioty, udzielając potrzebnego wsparcia: Departament Spraw Społecznych Urzędu Marszałkowskiego Województwa Kujawsko-Pomorskiego w Toruniu, Rzecznik Praw Ofiar przy Marszałku Województwa Kujawsko-Pomorskiego, Wydział Zdrowia i Polityki Społecznej Urzędu Miasta Torunia, Katolickie Stowarzyszenie „Civitas Christiana” Oddział Okręgowy w Toruniu, Polska Korporacja Akademicka Kujawja oraz Wydawnictwo WAM.

Sympozjum objęte zostało patronatem honorowym przez Marszałka Województwa Kujawsko-Pomorskiego, Piotra Całbeckiego, Prezydenta Miasta Torunia, Michała Zaleskiego, JE Biskupa Toruńskiego, ks. dr. An-

* Dr Piotr Chrzczonowicz, adiunkt w Katedrze Prawa Karnego i Polityki Kryminalnej Wydziału Prawa i Administracji Uniwersytetu Mikołaja Kopernika w Toruniu. 
drzeja Suskiego oraz Dziekana Wydziału Teologicznego UMK, ks. prof. dr. hab. Jana Perszona.

Pomysł przygotowania sympozjum dotyczącego zagadnień eschatologicznych związanych $\mathrm{z}$ działalnością różnych tak zwanych sekt i nowych ruchów religijnych zrodził się $\mathrm{w}$ związku $\mathrm{z}$ obecnymi w społeczeństwie i mającymi swój „rynek” wizjami końca czasów. Sam rok 2011 przyniósł już co najmniej kilka proroctw o zbliżającym się końcu świata, niekiedy wskazujących nawet na dokładne daty tego wydarzenia. Zapowiedzi na 2012 rok również prezentują wizje nadchodzącego Armagedonu, a wśród nich chyba najbardziej rozpowszechniona jest wizja finis mundi wynikająca z odczytów tak zwanego kalendarza Majów. Na naszych oczach w różnych rejonach globu ziemskiego rozkwitają więc przejmujące, napawające lękiem przepowiednie o rychłej i nieuniknionej totalnej katastrofie, która pochłonie świat i sprowadzi koniec dziejów. Przepowiednie takie pojawiają się niejednokrotnie w nauczaniu pewnych grup czy wspólnot o religijnym lub parareligijnym charakterze, które bywają zbiorczo określane jako sekty i nowe ruchy religijne. Postęp technologiczny w dziedzinie komunikacji stwarza sposobność ich łatwej dostępności, nośności i rezonansu w przestrzeni społecznej. Założeniem sympozjum było więc bliższe przyjrzenie się temu ważnemu wątkowi działalności różnych tak zwanych sekt i nowych ruchów religijnych, jako jednemu ze źródeł ich potencjalnej lub faktycznej destrukcyjności wobec norm społecznych, zarówno w odniesieniu do jednostek, jak i ich instytucji, w tym państwa. Wątek ten przeanalizowany został nie tylko przez pryzmat doktryn i praktyk współcześnie funkcjonujących wspólnot wpisujących się w konwencjonalną kategorię pojęciową ,sekty i nowe ruchy religijne”, lecz także z punktu widzenia wiedzy i doświadczeń nabytych z historii. Tłem dla rozważań nad tytułowym zagadnieniem konferencji stała się idea końca świata występująca w religii chrześcijańskiej, w jej tradycyjnych nurtach wyznaniowych, to jest w katolicyzmie, prawosławiu oraz protestantyzmie.

Sympozjum oficjalnie otworzył Dziekan Wydziału Teologicznego UMK - ks. prof. dr hab. Jan Perszon, który przywitał referentów i innych uczestników przedsięwzięcia naukowego oraz dokonał krótkiego wprowadzenia do jego problematyki. Program sympozjum obejmował trzy sesje tematyczne. Warto poczynić tu generalną uwagę, że zaprezentowane w nich referaty posiadały wysokie walory poznawcze, a problemy, które były w nich poruszane, zainspirowały do późniejszej dyskusji pozwalającej na jeszcze bliższe i dokładniejsze przyjrzenie się im.

W ramach I sesji zatytułowanej Eschatologia biblijna - interpretacje i oblicza możliwych zagrożeń (której przewodniczył piszący te słowa) wystąpili następujący referenci: ks. prof. dr hab. Janusz Bujak z Katedry Teo- 
logii Dogmatycznej Wydziału Teologicznego Uniwersytetu Szczecińskiego (Wybrane aspekty chrześcijańskiej eschatologii); prof. dr hab. Robert T. Ptaszek, kierownik Katedry Teorii Religii i Alternatywnych Ruchów Religijnych Wydziału Filozofii Katolickiego Uniwersytetu Lubelskiego Jana Pawła II (Apokalipsa i co dalej? O sposobach interpretacji biblijnych opisów końca świata) oraz Damian Dorocki, student teologii na Wydziale Teologicznym UMK (Eschatologia w nauczaniu adwentystów a poglady katolickie). Nie został niestety wygłoszony, z powodu absencji referenta, przewidziany w tej sesji w ramowej agendzie sympozjum referat prof. dr. hab. Macieja Szostaka z Katedry Kryminalistyki Wydziału Prawa, Administracji i Ekonomii Uniwersytetu Wrocławskiego (Kontrola grup o inklinacjach apokaliptycznych ze stanowiska bezpieczeństwa i porzadku publicznego).

Podczas drugiej sesji zatytułowanej Apokaliptyka w nauczaniu wybranych mniejszości religijnych $i$ sekt, nad którą przewodnictwo objął prof. Robert T. Ptaszek, swoje referaty przedstawili: dr Mariusz Gajewski SJ z Jezuickiego Centrum Edukacji w Nowym Sączu (Milenaryzm Świadków Jehowy. Krytyczna analiza idei końca świata głoszonych przez Towarzystwo Strażnica w świetle literatury przedmiotu); mgr Diana Sobieraj, doktorantka na Wydziale Filozofii Katolickiego Uniwersytetu Lubelskiego Jana Pawła II (Kwantowy wieloświat, samsara, a może coś jeszcze... czyli eschatologiczne propozycje Kościoła mormonów); ks. mgr lic. G. Daroszewski z Gdańskiego Centrum Informacji o Sektach i Nowych Ruchach Religijnych (Oczekiwanie na koniec świata $w$ doktrynie mormonów - referat przygotowany we współautorstwie z redaktor naczelną Biuletynu - kwartalnika o zagrożeniach duchowych, mgr Moniką Walczak, nieobecną na sympozjum); prof. dr hab. Viara Maldjieva z Instytutu Filologii Słowiańskiej Wydziału Filologicznego UMK (Paruzja oczami neognozy (na podstawie analizy tekstów Białego Bractwa)) oraz dr Katarzyna Tempczyk z Warszawy (Idea końca świata w mariawityzmie felicjanowskim (Kościele Katolickim Mariawitów)).

$\mathrm{Z}$ kolei w ramach trzeciej sesji sympozjum, zatytułowanej Przestania apokaliptyczne a nowoczesne technologie i panujace mody, w której zaplanowano pierwotnie wygłoszenie czterech referatów, zaprezentowany został - ze względu na nieobecność pozostałych referentów - jedynie referat lic. Marcina Garbowskiego z Katolickiego Uniwersytetu Lubelskiego Jana Pawła II (Od Matrixa do Skynetu - różne oblicza techno-apokalipsy w transhumanizmie). Zabrakło zatem ujętych w programie sympozjum i interesująco zapowiadających się wystąpień dr. Dariusza Hryciuka z Centrum Przeciwdziałania Psychomanipulacji w Lublinie (Apokaliptyczne obsesje w popkulturze. Analiza wybranych przykładów medialnych); dr Moniki Wojtkowiak z Instytutu Pedagogiki i Psychologii Wydziału Pedagogicznego i Artystycz- 
nego Uniwersytetu Jana Kochanowskiego w Kielcach (Wicca); dr Anny Nowakowskiej z Tychów (Idea zbawienia w nurcie New Age) oraz Tadeusza Połgenska z Fundacji Słowo Nadziei (Jak pomóc nie wejść do sekty?). Po tej okrojonej sesji, której przewodniczenie przypadło piszącemu te słowa, odbyła się ogólna dyskusja. Wzięli w niej udział obecni jeszcze na obradach referenci i inni uczestnicy, wśród których, co wymaga zasygnalizowania, od początku sympozjum panowała wysoka frekwencja, utrzymując się na dobrym poziomie aż do jego zakończenia. Dyskusja - będąca ostatnim punktem merytorycznej strony sympozjum - miała ożywiony i ciekawy przebieg. Uczestniczący w niej referenci (prof. R.T. Ptaszek, prof. V. Maldjieva, ks. mgr lic. G. Daroszewski, mgr D. Sobieraj, lic. M. Garbowski oraz D. Dorocki), poza sposobnością wypowiedzenia się co do podnoszonych kwestii związanych z ich wystąpieniami, mogli ustosunkować się także do innych pytań czy refleksji wpisujących się w obszar tematyczny sympozjum, a przedstawionych przez zabierających głos członków audytorium. Dyskusję moderował mgr Ireneusz Kamiński, reprezentujący Toruńskie Centrum Informacji o Sektach i Ruchach Religijnych. W konkluzjach dyskusji zwrócono między innymi uwagę na to, że tego typu spotkania, jak niniejsze sympozjum, pokazujące różne oblicza potencjalnych zagrożeń nie tylko duchowej natury, które wiążą się z upowszechnianiem (na ogół opartych na pewnych schematach myślowych) katastroficznych wyobrażeń końca świata w różnych grupach o aspiracjach religijnych, powinny przyciągać jeszcze więcej osób, zwłaszcza zaś ludzi młodych, stanowiąc dla nich dobre forum, na którym możliwe jest pozyskiwanie wiedzy, jak ustrzec się przed manipulacjami ze strony takich grup oraz z odpowiednim krytycyzmem i dystansem podchodzić do treści głoszonych w ich ofertach konfesyjnych.

Wypada dodać, iż przedstawione podczas sympozjum referaty zostaną opublikowane w postaci książkowej. 